\title{
Evaluating multifunctionality and adaptive capacity of mountain forest management alternatives under climate change in the Eastern Alps
}

\author{
Florian Irauschek ${ }^{1}$ (D) Werner Rammer $^{1} \cdot$ Manfred J. Lexer $^{1}$
}

Received: 26 August 2016/Revised: 17 April 2017/Accepted: 19 April 2017 / Published online: 5 May 2017

(C) The Author(s) 2017. This article is an open access publication

\begin{abstract}
Future provisioning of ecosystem services (ES) from mountain forests is uncertain due to potential impacts of climate change. For a case study catchment in the Eastern Alps in Austria we analysed how management and climate change may affect the provisioning of four ES (timber production, carbon sequestration, biodiversity and bird habitat quality, and protection against gravitational hazards). We used the PICUS forest ecosystem model to project seven management alternatives that differed with regard to cutting pattern size (SLIT, PATCH, STRIP) and two harvesting intensity levels (in terms of return interval) under historic climate and five transient climate change scenarios over 100 years. In addition no management and sanitary management were simulated. In total twelve indicators were linked to model output to quantify ES provisioning. Results under historic climate showed increased volume and carbon stocks in low-intensity management, while high-intensity management decreased stocks. Bird habitat quality was maintained only by lowintensity management using SLIT and PATCH cuts. In
\end{abstract}

Communicated by Harald Bugmann.

This article originates from the conference "Mountain Forest Management in a Changing World", held 7-9 July 2015 in Smokovec, High Tatra Mountains, Slovakia.

Electronic supplementary material The online version of this article (doi:10.1007/s10342-017-1051-6) contains supplementary material, which is available to authorized users.

Florian Irauschek

florian.irauschek@boku.ac.at

1 Institute of Silviculture, University of Natural Resources and Life Sciences (BOKU), Peter-Jordan-Straße 82, 1190 Vienna, Austria particular rockfall protection decreased strongly under the STRIP cut scenario. Improved tree growth in warming scenarios was counterbalanced by increasing damage from bark beetle disturbances. Canopy openings and increased deadwood supply from disturbances partly fostered bird habitat quality in no-management alternatives. Overall none of the management alternatives performed best for all ES. PATCH and SLIT regimes at (currently practiced) low intensity appeared as compromise to achieve multifunctionality at small scale. As involved trade-offs among ES can be substantial, partial segregation with priority on specific services in designated zones is recommended.

Keywords Mountain forest management - Ecosystem services $\cdot$ Multifunctionality $\cdot$ Climate change $\cdot$ Simulation

\section{Introduction}

Forests in the European Alps provide a wide variety of ecosystem services (ES) for owners and society by creating income through timber production, protecting infrastructure from gravitational natural hazards, providing highquality drinking water and mitigating climate change through the uptake and storage of carbon (Buttoud 2000; Price et al. 2000; Dorren et al. 2004; Nabuurs et al. 2014). Moreover mountain forests are important aesthetical assets for tourism (Nepal and Chipeniuk 2005). Despite intensive use for timber, fuelwood and livestock grazing since centuries, substantial shares of mountain forests in the Eastern Alps have been maintained in relatively natural state and are hotspots of biodiversity (Nagy et al. 2003; EEA 2010).

As a result of manifold demands for ecosystem services multifunctionality has been the main paradigm of forest policy and management in many European mountain 
ranges (e.g. Buttoud 2000; Hanewinkel 2011). However, the conceptual framework of multifunctional forest management aiming at integration of a bundle of ecosystem services at relatively small spatial scale (i.e. stand scale, comprising a few hectares) has rarely been made operational so far and lacks an explicit and transparent definition of management objectives and planning procedures for multiple ecosystem services (Suda and Pukall 2014). While recently an increasing number of studies on ES provisioning by mountain forests have become available, knowledge about ES trade-offs in dependence of forest management regimes is still limited (Briner et al. 2013; Häyhä et al. 2015; Uhde et al. 2015). While negative impacts of large-scale cutting pattern on place-based ES provision such as protection against rockfall and avalanche release are obvious (compare Dorren et al. 2004; Cordonnier et al. 2008), for other ES the relation between forest management and service provisioning levels may not be as straight forward.

Recently the potential impacts of climate change on forest growth, structure and composition and related ES provisioning have received a lot of attention (Carpenter et al. 2009; Rounsevell et al. 2010). Among various climate change impact mechanisms in particular abrupt tree mortality due to intensifying disturbance regimes has the potential to strongly impair the ability of forests to continuously provide ES such as timber production, carbon storage and protection against gravitative natural hazards (Thom and Seidl 2016). Homogeneous forests with high shares of conifers and poor structural and tree species diversity appear to be vulnerable to intensifying biotic disturbance regimes (Seidl et al. 2011; Griess et al. 2012; Temperli et al. 2012; Pasztor et al. 2014; Hlásny et al. 2015).

Current management regimes in European mountain forests are diverse and include, among others, stripwise clear cuts, shelterwood systems and various patch cutting approaches (cf. Nyland 1996; Burschel and Huss 2003). Local practices are often based on socio-economic and technological development and tradition (Heinimann et al. 2001; Brang et al. 2014; Bugmann et al. 2017). Current recommendations for the Eastern Alps emphasize smallscale cutting pattern to heterogenize the horizontal mosaic of stand structures (Ott et al. 1997; Motta and Haudemand 2000; Höllerl 2008) and are considering multiple ecosystem services at small spatial scale (i.e. stand scale, a few hectares). These recommendations have evolved as a result of practitioners' expertise and societal and stakeholders' demands towards forest ecosystems. However, under changing climatic conditions and intensifying disturbance regimes, experiences of the past may not be suitable any more. Because of low growth rates and high costs for management interventions in steep terrain, return intervals in mountain forests are longer compared to lowland forests. Considering the long lead times timely implementation of adaptive measures therefore is particularly crucial (e.g. Seidl et al. 2011) despite the uncertainty in magnitude and detailed properties of climate change as well as in future societal preferences for ES (e.g. Skourtos et al. 2010).

There is an urgent need to evaluate how different silvicultural regimes (i.e. cutting pattern for harvesting timber and tree regeneration) affect ES provisioning, and whether such management regimes are suitable to sustain ES provision under conditions of climate change. To achieve these goals and to provide science-based decision support in planning and decision-making, experiments utilizing advanced ecosystem modelling including disturbances and consideration of multiple ES are required (Wolfslehner and Seidl 2010; Muys et al. 2011).

In this contribution we set out to analyse the effects of alternative silvicultural management regimes and climate change on a set of ES (timber production, carbon storage, biodiversity and nature conservation, protection against gravitative hazards) for a catchment in the Eastern Alps in Austria employing a simulation-based scenario approach. Specifically the following questions will be addressed:

1. What are the effects of different silvicultural cutting patterns and turnover times on ecosystem services provisioning?

2. What is the impact of climate change on ecosystem service provisioning?

3. Are there interactions of climate change and management effects on ecosystem service provisioning?

\section{Methods and material}

\section{Study area}

The study area is situated in Vorarlberg in western Austria, in a side valley of the Montafon $(47.08 \mathrm{~N} ; 9.82 \mathrm{E})$. The forest is property of the Stand Montafon Forstfonds, an association owned by municipalities, that holds about 6500 ha of forest land in the region (Fig. 1a).

On crystalline and calcareous bedrock cambisols and rendzinas occur as main soil types. The current climate in the study region is characterized by low temperatures (long-term mean annual temperature at $1300 \mathrm{~m}$ a.s.l. is $6.2{ }^{\circ} \mathrm{C}$ ) and annual precipitation of $1486 \mathrm{~mm}$ with $901 \mathrm{~mm}$ occurring in the growing season from April to September. The natural forest types along an elevation gradient are mixed broadleaf forests of beech (Fagus sylvatica L.) with admixed maple (Acer pseudoplatanus L.) and ash (Fraxinus excelsior L.) at the valley bottom (approx. 800-900 m), mixed conifer forests of Norway spruce 
Fig. 1 Location of the study area (a), 53 stand polygons for establishing initial forest conditions (b), 18 harvesting units (HU) (c), and 1-ha grid cells $(n=220)$ for the analysis of ecosystem service provisioning (d)
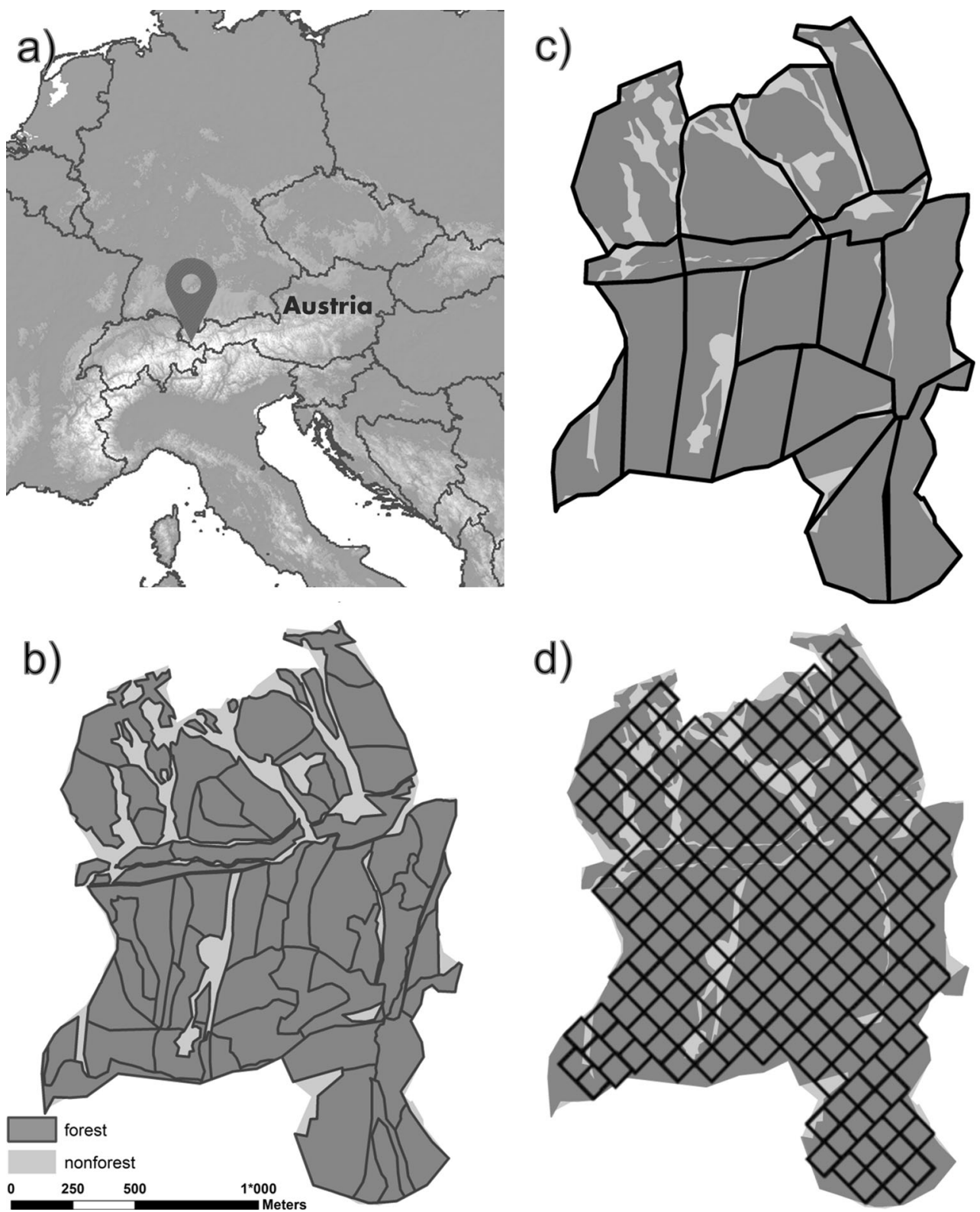

[Picea abies (L.) Karst.] and fir (Abies alba Mill.) with some admixed maple at intermediate elevation levels (approx. 900-1500 m), and spruce up to the timber line (approx. $1800 \mathrm{~m}$ ).

The region has a forest management history since at least 500 years (Bußjäger 2007). Land use has shaped landscape and forest structure through timber harvests and livestock grazing, which shifted the tree line downhill for alpine pasturing. In the last decades forest grazing has been abandoned in the study area (Malin and Maier 2007). Traditional forest management has mainly used patch cuts for timber harvests and stand regeneration, which resulted in uneven-aged forest structures in most stands. Due to low management intensity (partial cuts with long return intervals) the share of large old trees is considerable. Steep slopes and rough topography require timber harvesting based on skyline logging techniques. Forest and game management has favoured spruce, which is currently holding $88 \%$ of basal area share. Due to considerable densities of wild ungulates browsing pressure on regeneration of admixed tree species (i.e. fir, beech and maple) is high.

Current management objectives are to generate income from timber harvests while securing protection against landslides, rockfall and snow avalanche release (Malin and Lerch 2007). Major shares of the forest area are under Natura 2000 regulations, which aim at protecting habitat for black woodpecker (Dryocopus maritimus L.) and threetoed woodpecker (Picoides tridactylus L.) (Grabherr 2000). For the current study a catchment of 270 ha at elevations 
Table 1 Climate scenario characteristics for the case study at elevation $1300 \mathrm{~m}$ a.s.l; $\mathrm{c} 0=$ historic climate data (1961-1990), c1-c5 = changes in mean annual temperature $\left({ }^{\circ} \mathrm{C}\right)$ and precipitation (rel. change) in scenarios c1-c5 in relation to $\mathrm{c} 0$

\begin{tabular}{lllll}
\hline Climate scenario & Annual mean temperature & Annual precipitation & \multicolumn{2}{l}{ Summer precipitation } \\
\hline c0 & $\mathbf{6 . 2}\left({ }^{\circ} \mathbf{C}\right)$ & $\mathbf{1 4 8 6} \mathbf{~ m m}$ & $\mathbf{9 0 1} \mathbf{~ m m}$ & $\mathbf{C V}=\mathbf{1 6 \%}$ \\
c1 & +2.6 & $+20 \%$ & $+13 \%$ & $22 \%$ \\
c2 & +2.8 & $+2 \%$ & $-8 \%$ & $26 \%$ \\
c3 & $+7 \%$ & $-5 \%$ & $18 \%$ \\
c4 & +3.4 & $-1 \%$ & $-1 \%$ & $24 \%$ \\
c5 & +4.2 & $-9 \%$ & $-25 \%$ & $32 \%$ \\
\hline
\end{tabular}

Summer precipitation $=$ April to September, $\mathrm{CV}=$ coefficient of variation between 1060 and $1800 \mathrm{~m}$ a.s.l. has been selected because of demand for various ES by the landowner and the public, existing interest in active management and because Norway spruce is by far the most dominant tree species (see Fig. 1b).

\section{Climate data}

Historic climate data and five transient climate change scenarios covering 100 years up to 2100 were used as model input. They consist of daily values for temperature, precipitation, vapour pressure deficit and radiation. For the historic climate daily instrumental data for the period 1961-1990 from a nearby weather station were adjusted for site conditions in the case study regarding elevation and slope, utilizing algorithms from Thornton et al. (2000). Five climate change scenarios were based on simulations from the ENSEMBLES project (Hewitt and Griggs 2004), employing the A1B greenhouse gas emission scenario (IPCC 2007). For details on the downscaling approach see Bugmann et al. (2017). Climate scenario characteristics are shown in Table 1.

\section{Forest model}

We used the forest ecosystem model PICUS v1.5 (Lexer and Hönninger 2001; Seidl et al. 2005). PICUS v1.5 (henceforth referred to as PICUS) is a hybrid of classical gap model components (PICUS v1.2; Lexer and Hönninger 2001)) and a process-based stand-level net primary production model (3PG; Landsberg and Waring 1997). In PICUS growth, regeneration and mortality of individual trees are simulated utilizing a grid of $10 \times 10 \mathrm{~m}$ patches, topped by layers of crown cells of $5 \mathrm{~m}$ height each. A three-dimensional light model, used to estimate absorbed radiation for each tree, is a key component to connect the gap model elements to the production model. For detailed description of core model properties see Seidl et al. (2005). PICUS was successfully tested (Didion et al. 2009; Huber et al. 2013) and applied in various studies in Alpine forest ecosystems (Seidl et al. 2007b, 2011; Maroschek et al. 2015; Irauschek et al. 2017). The model provides accurate tree growth projections and furthermore captures key ecosystem processes such as spruce bark beetle (Ips typographus L.) disturbances, deadwood decay and tree regeneration including browsing by ungulates.

\section{Forest initialization}

A total of 53 stand polygons were delineated on a highresolution orthophoto for establishing the initial forest state. Based on a $50 \times 50 \mathrm{~m}$ raster a terrestrial inventory was carried out with at least five sample points per polygon using angle-count sampling (Bitterlich 1952) to collect information about diameter distribution and height-diameter relationship of trees above $5 \mathrm{~cm}$ diameter at breast height $(\mathrm{DBH})$. With concentric fixed radius plots regeneration structure and browsing damage of all smaller trees $(>10 \mathrm{~cm}$ height and $<5 \mathrm{~cm} \mathrm{DBH}$ ) were measured. Soil type, soil depth and water holding capacity were recorded from soil pits as described in Seidl et al. (2009). To establish a spatially explicit initial tree map for the 53 stand polygons (Fig. 1b), information from the inventory was combined with a LiDAR-based volume map and a normalized crown model (Hollaus et al. 2006, 2007). For each polygon trees are drawn from the related diameter distribution and assigned to that $10 \times 10 \mathrm{~m}$ patch of the virtual forest where the overall match with regard to (a) maximum, minimum and mean tree height from the crown model is highest, (b) total accumulated tree volume per patch does not exceed the corresponding value from the volume map and (c) total crown projection area of all trees on a patch does not exceed a specified maximum value (cf. Maroschek et al. 2015). For this study the landscape was divided into 18 harvesting units with sizes of 4-20 ha (Fig. 1c), which served as simulation entities. Main rationale for the delineation of the harvesting units was topography, which determines location of skyline tracks for efficient timber harvesting.

\section{Forest management}

Due to the steep terrain in the case study area trees are felled, delimbed and cut to length by chainsaw, and 
extracted to forest roads by cable yarding systems. A total of 131 skyline tracks were set out in the study area, considering topography and possible landing sites on forest roads. In all management scenarios timber harvests are bound to these skyline tracks. The suite of tested management alternatives included the currently practiced management approach as well as most of the currently discussed approaches for Norway spruce-dominated mountain forests (Ott et al. 1997; Streit et al. 2009; Brang et al. 2014). The management alternatives differ mainly in the spatial cutting pattern along the skyline tracks and the return interval. For a harvesting operation the skyline track of $5 \mathrm{~m}$ width is cleared of all trees $>10 \mathrm{~cm} \mathrm{DBH}$, and logging is implemented in a corridor of $25 \mathrm{~m}$ maximum lateral skidding distance (see Fig. 2).

The currently practiced harvesting operations (PATCH) feature irregularly shaped patches of 1500-2000 $\mathrm{m}^{2}$. To study effects of different cutting areas and pattern we included a slit cut scenario (SLIT), with small openings of $300 \mathrm{~m}^{2}$, and a strip cut scenario (STRIP), where harvests are concentrated on $5000 \mathrm{~m}^{2}$ strips along the skyline (Fig. 2; Table 2). Slit cuts are frequently recommended in mountain silviculture to initiate regeneration in protective forests (Streit et al. 2009), while strip cuts result in lower harvesting costs and more efficient artificial regeneration measures. We compared the three cutting patterns under current (LO) and increased (HI) harvesting intensity (cf.

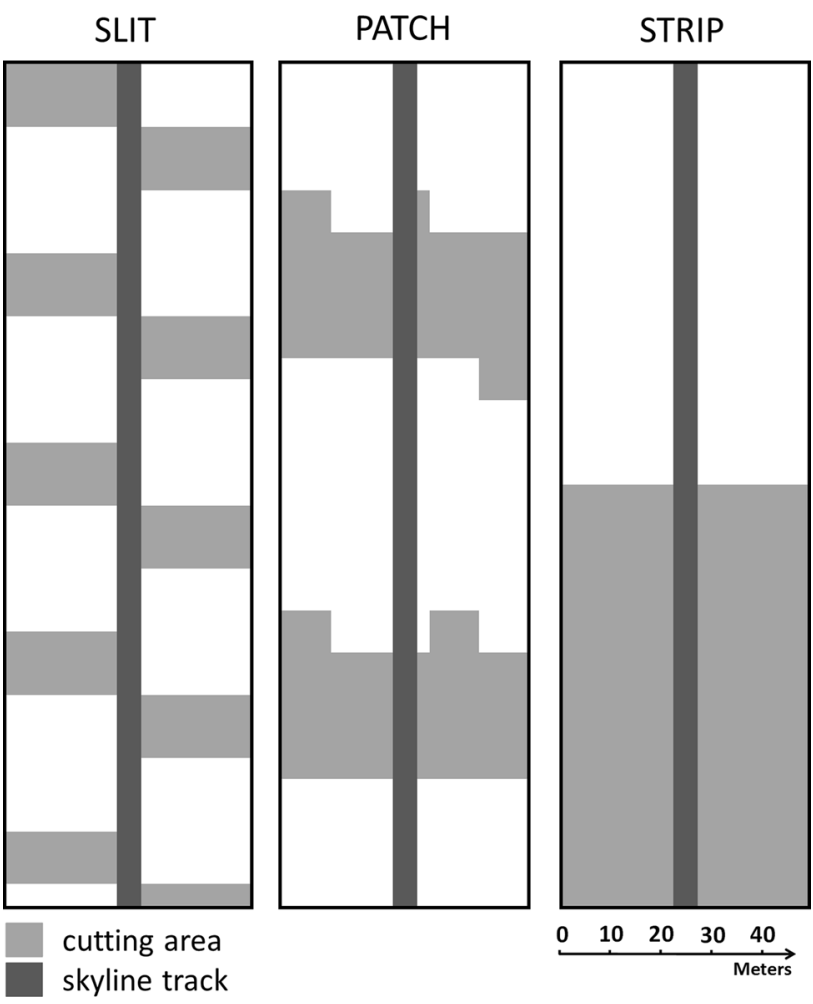

Fig. 2 Simulated harvesting pattern along skyline corridors
Table 2). In current management (PATCH-LO) each year on average 0.83 ha (i.e. $0-2$ skyline tracks) is subject to regeneration fellings, resulting in a theoretical complete area turnover of 250 years and an average return interval to the same skyline track of 84 years. Scheduling and selection of harvesting operations depend on tree maturity. Hence areas with older trees and higher stocking volume are harvested earlier. To avoid strong visual impacts harvesting operations are not implemented in adjacent skylines until tree regeneration is safely established. To represent increased harvesting intensity (HI scenarios) the return interval is reduced, so that the required area turnover time is 150 years. The general schedule and layout of the skyline tracks are the same in all scenarios. Moderate changes in sequence and timing of skylines are due to the adjacency constraint.

Two management variants were simulated using artificial regeneration: in STRIP-HI-P a mix of spruce, larch (Larix decidua Mill.), maple and fir is planted after felling operations in regular raster spacing of $2 \times 2 \mathrm{~m}$. Browsing effects (see "Browsing of tree regeneration by ungulates" section) are switched off for planted seedlings to mimic tree protection measures. In a sanitary felling scenario (SAN) bark beetle-infested spruce trees are felled, but remain on site after debarking. In the resulting gaps sycamore maple is planted and protected against browsing. For comparison a no-management regime (NOM) is simulated without silvicultural interventions and assuming current browsing probabilities. Details of the management alternatives are shown in Table 2.

\section{Browsing of tree regeneration by ungulates}

Based on the inventory (see "Climate data" section) the annual browsing probability for regeneration was calculated. In the simulation the browsing probability determines the fraction of simulated patches with available regeneration of a particular tree species that is browsed in any given year. Browsed patches are drawn randomly, and the height growth of the browsed species in that respective simulation year is set to zero. If a seedling is browsed in successive years (i.e. has zero height growth) it falls below the minimum growth requirement of the mortality algorithm and a fraction of saplings of the browsed species on that patch dies (see Table SM2-1). In all simulated management scenarios natural regeneration is subject to browsing.

\section{Ecosystem service indicators}

Cordonnier et al. (2013) presented a comprehensive set of indicators for ES provisioning by mountain forests as a 
Table 2 Key characteristics of management scenarios. Share harvested per set-up = share of skyline corridor area harvested per entry

\begin{tabular}{|c|c|c|c|c|c|c|}
\hline Short name & Description & $\begin{array}{l}\text { Cutting pattern } \\
(W \times L)[\mathrm{m}]\end{array}$ & $\begin{array}{l}\text { Share harvested } \\
\text { per set-up }\end{array}$ & $\begin{array}{l}\text { Return } \\
\text { interval }\end{array}$ & $\begin{array}{l}\text { Area turnover } \\
\text { [year] }\end{array}$ & Regeneration \\
\hline SLIT-LO & Slit cuts low intensity & $30 \times 10$ & $1 / 3$ & 84 & 250 & Natural \\
\hline PATCH-LO & $\begin{array}{l}\text { Irregular patch cuts low } \\
\text { intensity }\end{array}$ & $50 \times 30-40$ & $1 / 3$ & 84 & 250 & Natural \\
\hline STRIP-LO & Strip cuts low intensity & $50 \times 100$ & $1 / 2$ & 126 & 250 & Natural \\
\hline SLIT-HI & Slit cuts high intensity & $30 \times 10$ & $1 / 3$ & 50 & 150 & Natural \\
\hline PATCH-HI & $\begin{array}{l}\text { Irregular patch cuts high } \\
\text { intensity }\end{array}$ & $50 \times 30-40$ & $1 / 3$ & 50 & 150 & Natural \\
\hline STRIP-HI & Strip cuts high intensity & $50 \times 100$ & $1 / 2$ & 76 & 150 & Natural \\
\hline STRIP-HI-P & $\begin{array}{l}\text { Strip cuts high } \\
\text { intensity }+ \text { planting }\end{array}$ & $50 \times 100$ & $1 / 2$ & 50 & 150 & $\begin{array}{l}\text { Natural + planting spruce, } \\
\text { larch, maple, fir }\end{array}$ \\
\hline NOM & No management & - & - & - & - & Natural \\
\hline SAN & Sanitary management & - & - & - & - & Natural + planting maple \\
\hline
\end{tabular}

major outcome of the ARANGE FP7 project (Advanced Multifunctional Forest Management in European Mountain Ranges). For the current study a total of 12 ES indicators were selected to represent the provision of timber, carbon storage, biodiversity and bird habitat, and protection against the gravitational hazards rockfall, snow avalanches and landslides. Below a brief description of the indicators is provided; for details see Supplementary Material SM1.

Timber production was represented by volume of living trees (V), harvested commercial volume (TVH), periodic net volume increment (VI) and volume of trees killed by bark beetles (BBD). Carbon sequestration was assessed by total carbon $(\mathrm{C})$, including carbon in tree biomass, standing deadwood, woody debris and soil carbon. Biodiversity and nature conservation were represented by tree species diversity (DSP), tree size diversity (DSI) and bird habitat quality (BHQ). The latter characterized habitat for woodpeckers which are considered as important umbrella species for nature conservation (Drever et al. 2008). BHQ is a composite indicator considering standing large deadwood, large living trees and canopy cover. It was provided on an ordinal scale (good, medium, poor). Protection against gravitational hazards was represented by four indicators: an avalanche protection index (API) expressed the ability of a stand to prevent avalanche release; a rockfall protection indicator (RPI) (for rock diameter $0.46 \mathrm{~m}$ ) quantified the percentage of falling rocks passing through a forest stand; and a landslide protection index (LPI). API was based on basal area and mean DBH, RPI used stem number, basal area and mean DBH as stand characteristics for input, and LPI was calculated from canopy cover of trees $>5 \mathrm{~cm}$ DBH. API and RPI were measured on interval scale [0-1], where values of 1 indicate an optimal protective effect; LPI was provided on ordinal scale (good, medium, poor).
In addition to these ES indicators a regeneration indicator (REG) was provided for all simulation runs characterizing regeneration dynamics and indicating availability of young trees for the further development of the forest. REG specified the area share of the landscape with at least 50 saplings per ha in height class $80-130 \mathrm{~cm}$.

\section{Assessment approach}

The nine management alternatives (Table 2) were each simulated under historic climate and five climate change scenarios (Table 1). To account for the variation in indicator results due to stochastic algorithms in the PICUS simulation environment, each simulation unit was simulated ten times. Altogether for each of the 18 simulation units 540 runs were conducted $(9 \times 6 \times 10)$. Model output (single tree attributes) was mapped onto a digital elevation model and analysed utilizing the PICUS landscape assessment tool (see Maroschek et al. 2015). First the mean values from the ten replicates for all intermediate variables feeding into indicator calculation were prepared. Then the indicators for timber production and carbon sequestration were aggregated at the level of the 18 harvesting units (mean values), and finally an area weighted average was calculated at landscape scale. Indicators for biodiversity, nature conservation and protection against gravitational hazards which require a smaller spatial context were calculated for 220 1-ha pixels (see Fig. 1d). For the interval scaled protection indicators (API and RPI) and the tree diversity indicators (DSP and DSI), the 10th, 50th and 90th area percentiles (P10, P50, P90) were calculated to characterize the worst, the mean and the best pixel values of the catchment. For the categorical indicators LPI and BHQ the 
landscape area percentage of the three categories was calculated.

To represent the development of ES provisioning over time for further analysis, the indicators were provided in three assessment periods (period P1: 2000-2032, period P2: 2033-2066, period P3: 2067-2100), as periodic mean, modal or minimum value (for details see Table SM1-1).

Before analysing the effects of climate change and management on ES provisioning, we evaluated the modelinduced variation in ES indicators. Simulated indicator values vary depending on the interplay of stochastic model elements, which in turn affect forest structure and composition. Per management $\times$ climate combination the coefficient of variation (CV) from the ten replicates was calculated for the indicators in period P3. The categorical indicators LPI and BHQ were included as the area share rated in category "good". To test the effects of management, climate and their interaction in P3 on (1) ES indicators and (2) CVs of indicators, we employed ANOVA tests using general linear models and Tukey tests. All statistical tests were conducted with the $\mathrm{R}$ language and environment (R Core Team 2016) utilizing the "TukeyC" package (Faria et al. 2016).

\section{Results}

First we briefly compare the temporal development of ES indicators under different management alternatives and historic climate to reflect the transient behaviour of ES provisioning in the study landscape. Then we focus on the assessment period P3 and show how management and climate affect the long-term development of ES indicators. Finally we synthesize the results and compare all management alternatives with regard to simultaneous provisioning of all ES. An evaluation of the model-induced variation in ES indicators as a prerequisite to interpret differences in ES indicators among scenarios is provided in Supplementary Material (SM3).

\section{Temporal development of ES provisioning}

Forests in the study region were not in steady state conditions, but evolved and showed transient behaviour over the 100-year analysis period. All scenarios started from the same initial forest conditions, and differences in ES indicator trajectories within a specific climate scenario are due to effects of management alternatives. Figure 3 shows the temporal development over three assessment periods for all indicators under historic climate. Harvested volume per hectare and year (TVH) increased over time in all management scenarios. Reasons were the predefined sequence and constraints of the skyline harvesting pattern, which fixed the amount of harvested area per period (see "Forest management" section), and the increasing mean volume stock on the scheduled cutting areas. Mean periodic volume increment (VI) increased as well because, as a result of the cutting activities and related regeneration, the average tree age decreased. In contrast in NOM and SAN alternatives (i.e. management scenarios without timber harvests) forest growth started to decline in the final assessment period due to overmature trees. Under the historic climate damage by bark beetles (BBD) was similar under all management alternatives $\left(0.4-0.5 \mathrm{~m}^{3} \mathrm{ha}^{-1}\right.$ year $^{-1}$ ) and did not change much over time (Fig. 3). Stocks of volume (V) and carbon (C) increased over time in all low-intensity management alternatives as well as in the NOM and SAN scenarios. In high-intensity scenarios volume and carbon stocks were lower in period P3 compared to the initial period P1. Interestingly species diversity (DSP) showed a moderately decreasing trend under all management regimes except in the STRIP-HI-P alternative with planting. Tree size diversity (DSI) increased in general. However, in STRIP-HI and SAN management this development was dampened in P3, while in the NOM scenario tree size diversity did not increase at all due to missing active regeneration initiation. Bird habitat quality (BHQ) was maintained in PATCH-LO and SLIT-LO scenarios (approx. 50\% of the area rated as "good"; Fig. 3), whereas in all other management alternatives bird habitat quality showed an unfavourable trend. While protective effects against avalanche release (API) and landslides (LPI) in general improved under all management regimes, rockfall protection (RPI) improved only in low-intensity and no-harvest variants (NOM and SAN). In STRIP-LO and all high-intensity scenarios rockfall protection decreased in the intermediate period P2 only to recover in period P3 to approximately the initial values. The regeneration indicator (REG) revealed one general trend: the area share with regeneration increased until period $\mathrm{P} 2$ and dropped then in most management scenarios to the level of period P1 or even less. Only the small-scale alternatives SLIT-HI and PATCH-HI maintained high area shares with regeneration in period $\mathrm{P} 3$.

\section{Long-term effects of management and climate on ES provisioning}

Effects of management and climate scenarios on ES provisioning emerged and accumulated over time. ANOVA results showed that in the final assessment period P3 for all analysed indicators effects of management and climate, as well as the interaction of these two factors, were significant (Table SM4-1 in Supplementary Material). However, it is acknowledged that in many cases differences were rather small and from a management perspective not relevant. 

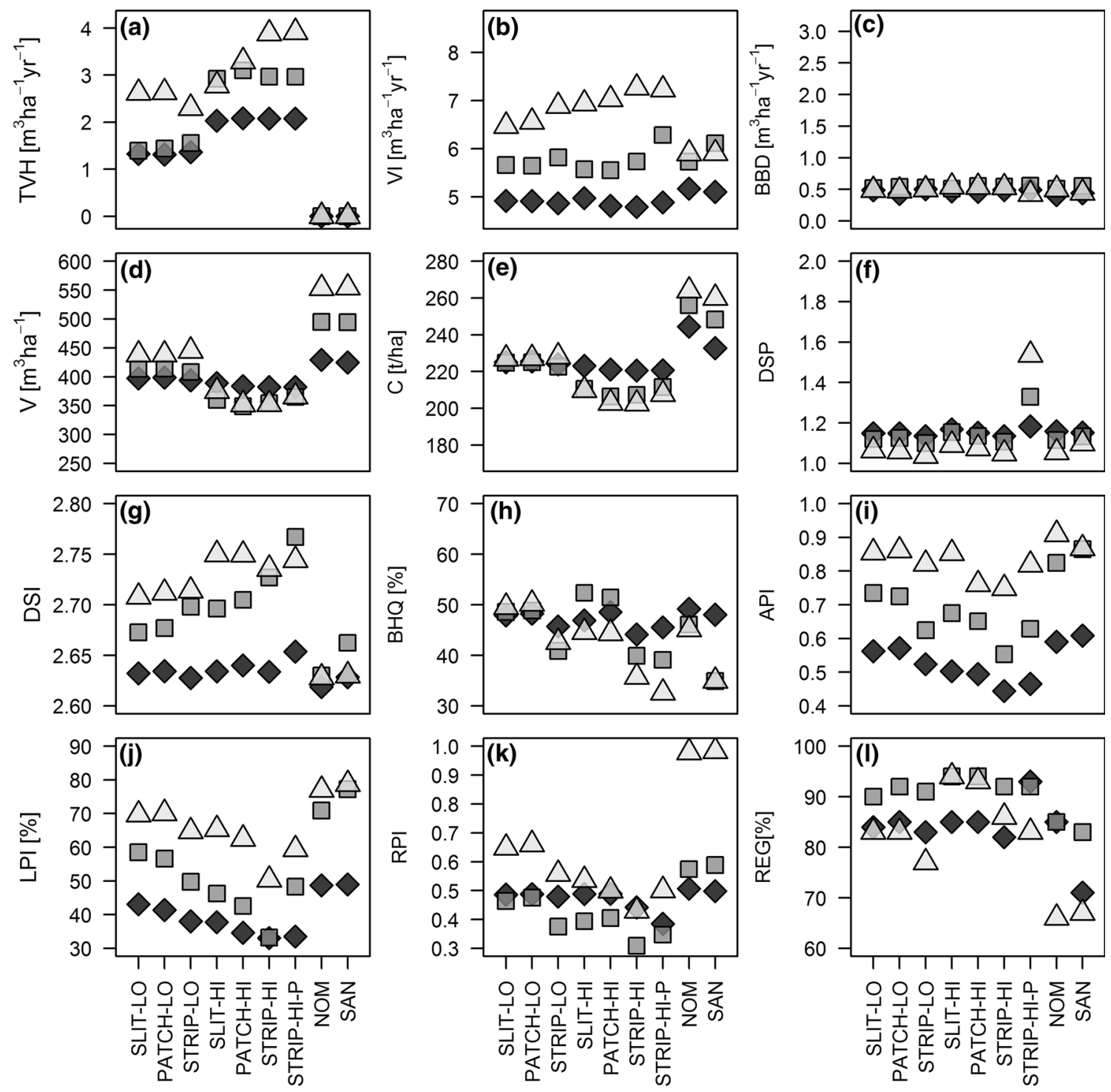

Period 1 (2000-2032) $\square$ Period 2 (2033-2066) $\triangle$ Period 3 (2067-2100)

Fig. 3 Temporal trend of ES indicators in nine management alternatives under historic climate $(\mathrm{c} 0)$ over three assessment periods (P1, P2, P3) from 2000 to 2100 . DSI is represented by 50th percentile,

Below results for all indicators are discussed by ES. Figure 4 shows all ES indicators in P3 for each management alternative under all climate scenarios. In Supplementary Material detailed indicator values are shown including Tukey test results for differences between management scenarios (Tables SM4-2 to SM4-7) and for differences between climate scenarios (Table SM4-8).

\section{Timber production}

In historic climate total harvested timber volume (TVH) over the entire 100 year assessment period under low management intensity ranged from 174 (STRIP-LO) to
API and RPI by 10th percentile and LPI as share of area in category "good", all other indicators by mean values

$180 \mathrm{~m}^{3} \mathrm{ha}^{-1}$ (PATCH-LO). In general high-intensity scenarios harvested significantly more (on average 58-60\%). Under climate change total harvested timber decreased, with the largest drop (i.e. 10\%) occurring in climate scenario c5 (not shown). Looking at period P3 alone the same pattern emerged and harvested volume of high-intensity alternatives was on average between 39\% (in historic climate) and $37 \%$ (climate scenario c5) higher than in the low-intensity alternatives (Fig. 3; Tables SM4-2 to SM47).

For volume increment (VI) two trends were apparent: First in high-intensity management productivity was significantly higher in all climate scenarios 

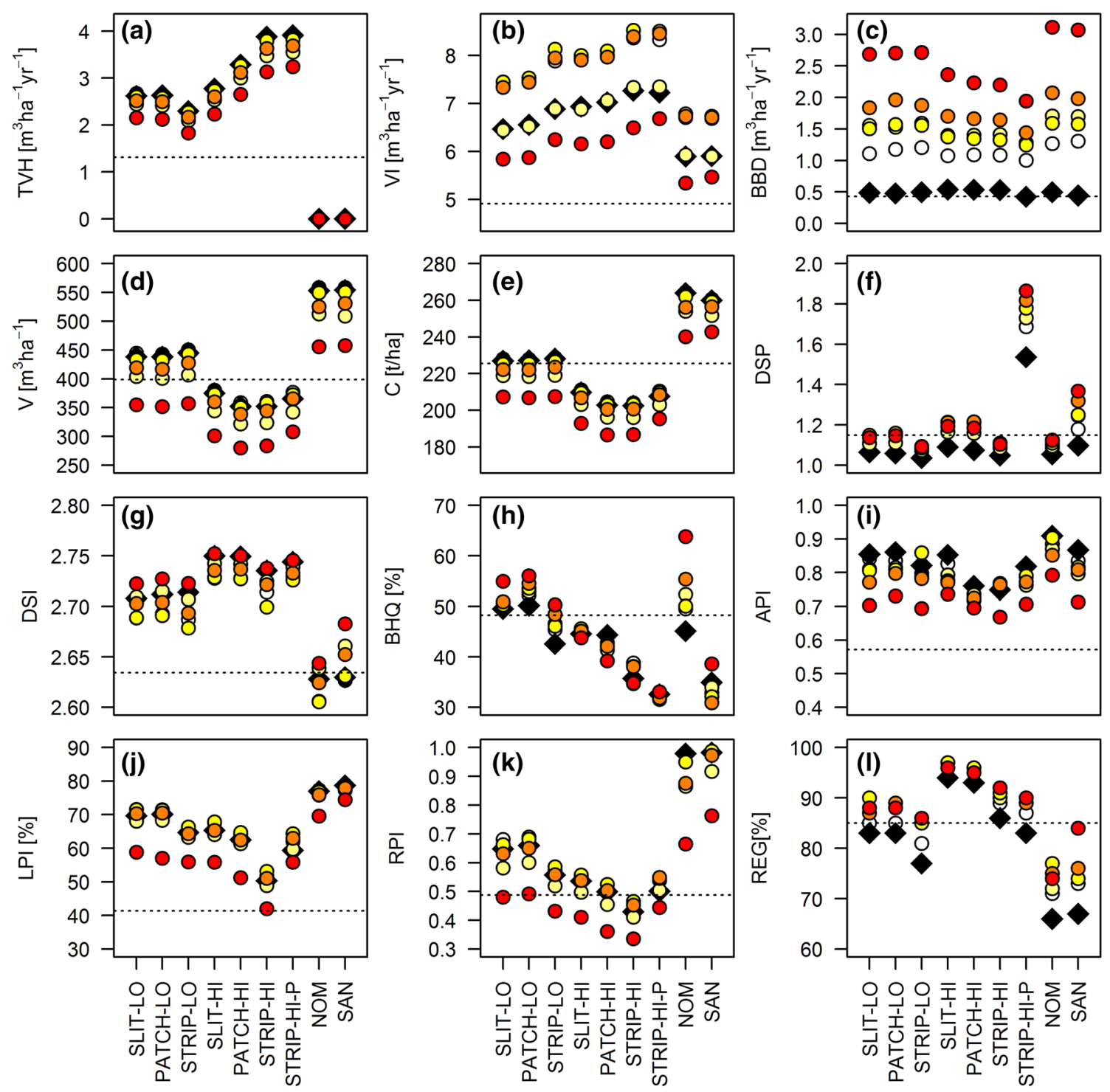

c0 O c1 O c2 O c3 $\bigcirc$ c4 ○ c5

Fig. 4 Ecosystem service indicators in nine management alternatives and six climate scenarios $(\mathrm{c} 0=$ current climate, $\mathrm{c} 1-\mathrm{c} 5$ are climate change scenarios). Shown are mean values for the period P3 (2067-2100). Corresponding values in P1 under PATCH-LO and

[6.4 $\mathrm{m}^{3} \mathrm{ha}^{-1}$ year $^{-1}$ (c5) to $8.3 \mathrm{~m}^{3} \mathrm{ha}^{-1}$ year $^{-1}$ (c3)] compared to low-intensity management $\left[6.0 \mathrm{~m}^{3} \mathrm{ha}^{-1}\right.$ year $^{-1}$ (c5) to $7.7 \mathrm{~m}^{3} \mathrm{ha}^{-1}$ year $^{-1}$ (c3)] and to no-harvest alternatives NOM and SAN $\left[5.5 \mathrm{~m}^{3} \mathrm{ha}^{-1}\right.$ year $^{-1}$ (c5) to $6.8 \mathrm{~m}^{3} \mathrm{ha}^{-1}$ year $^{-1}$ (c3)]. The reason was the faster turnover of the initial tree population and consequently a resulting lower mean tree age. Second warmer temperatures of climate change scenarios fostered tree growth. Compared to historic climate net increment increased under all climate change scenarios except the strongest warming scenario c5, independent of the management alternative (Fig. 4). However, under the moderate warming historic climate $\mathrm{c} 0$ as reference are shown as dotted line. DSP and DSI are represented by 50th percentile, API and RPI by 10th percentile and LPI and BHQ as share of area rated as "good". (Color figure online)

scenario c2 gains were negligible and not significant (Table SM4-8).

Under historic climate damaged timber by bark beetles (BBD) was very similar for all management alternatives. Climate change conditions caused a strong increase in damages, particularly under scenario c5. There was a trend of higher damages in NOM and SAN, followed by lowintensity alternatives, while high-intensity management variants tended to have lower damages (Fig. 4). Overall the cutting pattern did not affect bark beetle damages significantly except in c5, where SLIT-HI had higher damages than PATCH-HI and STRIP-HI. Comparing NOM and 
STRIP-HI-P it was obvious that the influence of management as a possible measure to reduce bark beetle damages [between $0.3 \mathrm{~m}^{3} \mathrm{ha}^{-1}$ year $^{-1}$ (c1) and $1.2 \mathrm{~m}^{3} \mathrm{ha}^{-1}$ year $^{-1}$ (c5) higher in NOM] was considerably lower than the expected damage increase due to climate change [between $+0.7 \mathrm{~m}^{3} \mathrm{ha}^{-1}$ year $^{-1}$ (c1) and $+2.7 \mathrm{~m}^{3} \mathrm{ha}^{-1}$ year $^{-1}$ (c5)] (Table SM4-2 to SM4-7).

Volume stock is closely related to all other timber indicators. Under historic climate NOM and SAN accumulated 553-554 $\mathrm{m}^{3} \mathrm{ha}^{-1}$ volume stock, while all managed scenarios resulted in significantly lower standing volume, with high-intensity scenarios always lower than low-intensity scenarios (lowest volume in PATCH-HI and STRIP-HI: $352 \mathrm{~m}^{3} \mathrm{ha}^{-1}$ ). Impacts of climate on volume stocks ranged from slight increases $\left(+5 \mathrm{~m}^{3} \mathrm{ha}^{-1}\right.$ in scenario $\mathrm{c} 1$ ) to significantly reduced volume (scenario c2: $-8 \%$, c4: $-4 \%$, c5: $-20 \%$; average values over all management alternatives; see Table SM4-2 to SM4-8).

\section{Carbon storage}

In historic climate under low-intensity management carbon stocks were on average $227 \mathrm{t} \mathrm{ha}^{-1}$. High-intensity alternatives reduced carbon stocks significantly $(-8$ to $-11 \%)$, while no-harvest scenarios significantly increased stocks $(+14$ to $+16 \%)$ (Table SM4-2).

Climate change resulted in small increases in carbon under scenario $\mathrm{c} 1$ and minor negative effects in climate scenarios c3 and c4 (Fig. 4). Under conditions of climate change scenarios $\mathrm{c} 2$ and c5 carbon stocks were significantly reduced ( -2 to $-4 \%$ in $\mathrm{c} 2$, and -6 to $-9 \%$ in $\mathrm{c} 5$, depending on management). The decrease was significantly different between high- and low-intensity and no-harvest scenarios, with strongest reduction under the latter and smallest in high intensity management scenarios (Tables SM4-2 to SM4-8).

\section{Biodiversity and nature conservation}

Under historic climate the differences in tree species diversity (DSP) between management alternatives with natural regeneration were rather small, although partly significant [e.g. 50th percentiles (P50) of DSP from 1.04 to 1.09; Table SM4-2]. Independent of management intensity SLIT and PATCH cutting pattern promoted slightly higher species diversity compared to STRIP alternatives. Not surprisingly the alternatives including planting of broadleaves (STRIP-HI-P and SAN) yielded the highest species diversity (DSP P50 of 1.54 and 1.10, respectively). Species diversity in NOM was similar to the managed scenarios (DSP P50 of 1.05). In all management alternatives the highest species diversity occurred in climate scenarios $\mathrm{c} 4$ or c5 (Tables SM4-2 to SM4-7).
Also for tree size diversity (DSI) results under historic climate were fairly similar. In all low- and high-intensity scenarios DSI P50 ranged from 2.71 to 2.75. In NOM and SAN tree size diversity was moderately lower (DSI P50 of 2.63; Table SM4-2). Impact of climate change scenarios was very low (although partly significant; Table SM4-8), comprising of small decreases and small increases (the latter in NOM, SAN and LO alternatives under climate c5). For DSI the impact of climate change was generally lower than the effect of management.

Under historic climate PATCH-LO and SLIT-LO provided the highest share of suitable bird habitat (BHQ) with 49.6 and $50.2 \%$ of landscape area in the highest category (Table SM4-2). All other alternatives provided significantly less suitable habitat with STRIP-HI variants $(35.7 \%$ for STRIP-HI and $32.6 \%$ for the planting variant STRIPHI-P) and SAN (35.0\%) producing the lowest area shares.

Climate change affected the area of suitable bird habitat differently depending on management. In general climate change caused more standing deadwood and canopy openings in dense areas of the landscape. As a result lowintensity alternatives, NOM and SAN had best habitat conditions under the strongest warming scenario c5. Interestingly under climate scenario c5, NOM provided highest shares of suitable bird habitat. In high-intensity variants highest area share of good bird habitat was generated under milder climate change scenarios (Table SM4-8).

\section{Protection against gravitational hazards}

While 50th and 90th percentiles of the avalanche protection indicator (API P50 and API P90) remained at optimum value of 1.0 under all management and climate scenarios, the worst $10 \%$ (API P10) responded negatively to climate change scenarios (Table SM4-8). NOM was best under all climate scenarios (API P10 between 0.88 in scenario $\mathrm{c} 0$ and 0.79 in scenario c5). The SAN scenario showed a reasonable performance under historic climate (API P10 of 0.87 , not significantly different from NOM), but fell back under climate change scenario c5 (API P10 of 0.71). PATCH-HI and STRIP-HI were constantly the least performing management alternatives (Tables SM4-2 to SM4-7).

Management had pronounced long-term influence on landslide protection (LPI). Under historic climate management intensity and cutting pattern caused impacts of approximately the same order of magnitude. At both intensity levels STRIP produced significantly lower area share in category "good" compared to SLIT and PATCH management (Table SM4-2). Generally low-intensity variants provided better landslide protection. SLIT-HI was best among the high-intensity variants and not significantly 
different from the worst variant under low intensity (STRIP-LO). When comparing STRIP-HI and STRIP-HI-P significant positive effects of artificial regeneration were observed. However, landslide protection remained below PATCH and SLIT variants.

Compared to historic climate (c0) severe climate change (c5) yielded negative impacts on LPI under all management alternatives. Under conditions of $\mathrm{c} 5$ the NOM alternative still provided $69.6 \%$ of landscape area in the best LPI category (Table SM4-7).

As indicated by P50 and P90 of the rockfall protection indicator (RPI) forest conditions were sufficient to protect against rocks of $46 \mathrm{~cm}$ diameter on large shares of the landscape regardless of climate scenario (Tables SM4-2 to SM4-7). However, the worst $10 \%$ of the landscape area (i.e. P10) provided just low protective effect against falling rocks (RPI P10 between 0.66 under PATCH-LO in scenario c0 and 0.34 under STRIP-HI in scenario c5). Highintensity management had adverse effects on rockfall protection, and STRIP alternatives were the least preferable cutting patterns. In HI management SLIT was significantly better than PATCH. NOM and SAN maintained high protective effect (RPI P10 between 0.99 and 0.87 ) under all climate scenarios except c5. In climate scenario c5 RPI P10 decreased to 0.67 (NOM) and 0.76 (SAN), respectively.

\section{Effect of management regimes on multifunctionality}

In Fig. 5 performance profiles of management alternatives under historic climate (c0) and one selected climate change scenario (c5) summarize the provision of ES in the study area. It is apparent that no single alternative was best in all indicators. High-intensity management was generally preferable from a timber production perspective. However, the harvest rates were still below the increment and it was just under strong warming scenarios (e.g. c5) that climaterelated tree mortality, including bark beetle damaged stems, resulted in a net loss in volume stocks. For protection services, carbon sequestration and partly for the biodiversity and nature conservation indicators, high-intensity alternatives were the least preferable options. NOM and SAN maintained high carbon stocks and provided better protection against gravitational hazards than any of the other alternatives. SLIT-LO and PATCH-LO provided best bird habitat, but were outperformed in all other services and indicators by either the respective high-intensity variant (for timber production) or one of the no-harvest alternatives (NOM, SAN). Regarding tree species and structural diversity there were just minor differences among alternatives. However, in none of the ES indicators low-intensity variants ranked last.

Essentially the performance profile under severe climate change conditions of scenario c5 appears similar. However, a major shift in ranks occurred with regard to damaged timber from bark beetle disturbances and in bird habitat provisioning. In NOM and SAN damages caused by the intensified disturbance regime were higher than in any other management alternative. However, disturbances had also positive effects on bird habitat quality by generating deadwood and opening the dense canopy. From Fig. 5 it is also apparent that the effect of management intensity on ES provisioning was larger than the effect of cutting pattern under both historic climate $\mathrm{c} 0$ and strong warming scenario c5. STRIP cutting pattern were negatively impacting protection services and bird habitat quality at low- and highintensity level. High-intensity alternatives generated the largest area with tree regeneration, as indicated by the REG indicator. However, due to strong browsing pressure on admixed fir and broad-leaved species, the tree species diversity did not increase much (under climate change scenarios) or not at all (in historic climate).

\section{Discussion}

\section{Study design and model limitations}

The comprehensive scenario matrix in our simulation study covered 54 management $\times$ climate combinations and provided insight in potential future pathways of forest management in steep coniferous mountain forests and related ES provisioning. The silvicultural cutting patterns to harvest timber and to regenerate the forest include all major feasible options for cable yarding terrain. Patch and strip cuts concentrate timber harvests in space and time and avoid the diffuse dispersal of single stem removals of individual tree selection and shelterwood systems (Burschel and Huss 2003; Weinfurter 2013). This keeps damage to residual stems low and increases harvesting efficiency (Stampfer 2000).

Recently several studies (e.g. Temperli et al. 2012; Villa et al. 2014) emphasized the importance of scaling to bridge the gap between stand-level indicators and landscape level ES provisioning. Based on spatially explicit simulations in the current study different approaches to calculate ES indicators were used. In particular indicators that do not scale linearly with area, such as bird habitat quality and protection service indicators, require a specific spatial context. The 1-ha size of the raster cells that were used to calculate most ES indicators in the current study can be evaluated from two perspectives. Cutting areas of simulated PATCH and SLIT regimes with 1500 and $300 \mathrm{~m}^{2}$, respectively, were several times smaller than the 1-ha analysis raster cells. Thus these raster cells were large enough to capture the spatially heterogeneous texture of mountain forests. The 1-ha cells were, on the other hand, 
(a)

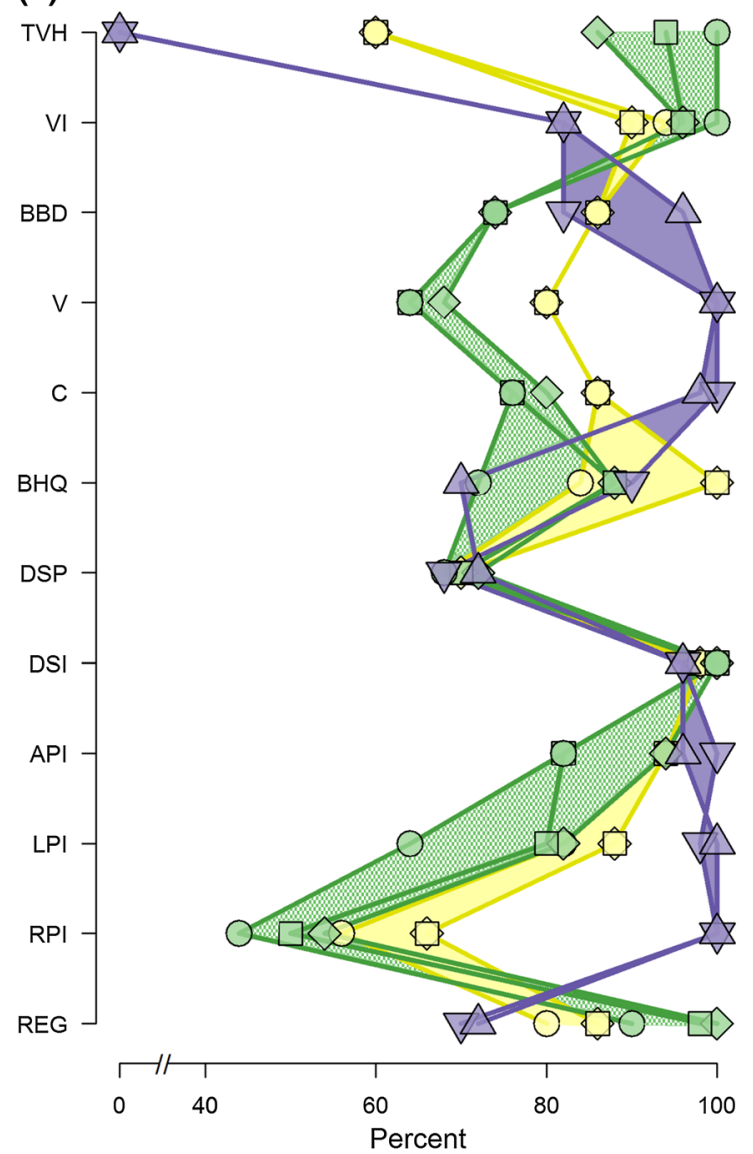

(b)

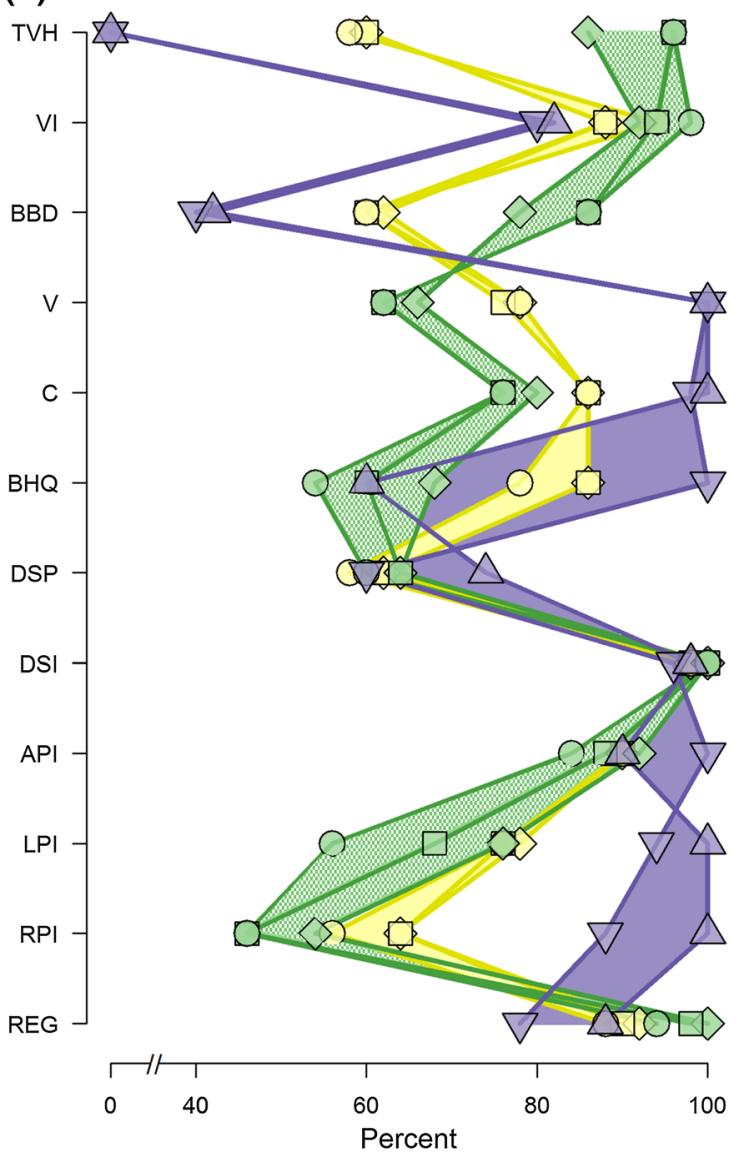

$\diamond$ SLIT-LO $\diamond$ SLIT-HI $又$ NOM $\square$ PATCH-LO $\square$ PATCH-HI $\triangle$ SAN $O$ STRIP-LO $=$ O STRIP-HI

Fig. 5 Ecosystem service indicators in period 3 relative to best management scenario according to preference direction. Left plot (a) shows results under historic climate and right plot (b) climate change scenario c5. Colored band depicts range for management intensities [low intensity $(\mathrm{LO})=$ yellow, high intensity $(\mathrm{HI})=$ green

small enough to provide a suitable spatial context for ES such as protection against gravitational hazards and habitat quality. However, representing the frequency distribution of 1-ha samples of an ES indicator by three different percentiles (P10, P50, P90) increased complexity and the need for more detailed explanations. In providing this spatial context in ES indicators we are in line with Grêt-Regamey et al. (2014) and Raudsepp-Hearne and Peterson (2016). Overall we believe that our approach improved ES quantification substantially compared to other studies (e.g. Marzluff et al. 2002; Elkin et al. 2013; Malek et al. 2015). Upscaling of stand-level ES indicators, by weighting indicator results with respective represented area in the landscape, does not provide unbiased estimates for ecosystem service indicators that do not scale linearly (e.g. Hlásny and Turčáni 2013; Hlásny et al. 2014). Other (pattern), NOM and SAN $=$ purple). DSP and DSI are represented by 50th percentile, API and RPI by 10th percentile, LPI and BHQ as share of area rated as "good" and TVH as sum over 3 periods. (Color figure online)

studies used non-spatial point models (Pabst et al. 2008; Mina et al. 2015) that cannot mimic effects of patch and slit cuts.

Regeneration dynamics are a key feature in mountain forests. In the PICUS model light is the major driver for the establishment and early growth of regeneration. The light regime on the forest floor is linked to management interventions and natural disturbances. While the light regime is considered at a high level of detail in the model, ground vegetation that may suppress tree regeneration is not considered explicitly. In mountain forests suitable regeneration niches are found at gap edges (e.g. Streit et al. 2009). If gaps in the canopy (i.e. regeneration cuts) get too large, the ratio of gap edges to gap area increases and most of the gap area will be populated with shade intolerant ground vegetation species such as Rubus sp. and grass species (e.g. 
Calamagrostis sp.) that may impede tree regeneration. Particularly in the STRIP variants the simulated results for natural regeneration may thus be too optimistic.

\section{Disturbances as key driver of forest development in a warmer climate}

Overall our study supports the theory that tree growth, in the cool-wet conditions observed in the subalpine region in the European Alps, is currently limited by temperature and may therefore profit from a warming climate (cf. Lindner et al. 2010; Elkin et al. 2013; Hartl-Meier et al. 2014; Helama and Sutinen 2016). Simulation results showed a significant increase in productivity in three out of five climate change scenarios compared to current climate. Nevertheless results for two climate change scenarios also revealed that changes in the precipitation regime can inhibit or even reverse this trend (cf. Büntgen et al. 2006). In addition the host-insect system of Norway spruce and the spruce bark beetle is highly sensitive to climatic changes, as both beetle development and host tree defences are dependent on climate variables (Netherer and Schopf 2010; Weed 2013). As a result bark beetle disturbances are expected to intensify in a warmer climate (Bentz et al. 2010) and have significant influence on development of spruce-dominated forests much earlier than direct effects of climate on forest growth. In the study area other disturbance agents, such as storms (cf. Schelhaas et al. 2003), have not been relevant so far and are not considered as important in the future (Kromp-Kolb et al. 2014). Our simulation results show that part of the warming-induced gain in volume increment was set off by tree mortality, particularly from bark beetle disturbances. We simulated a strong increase in frequency and intensity of disturbances in warmer climates, and in the strongest warming scenario (c5) disturbance damage at the end of the assessed period was as high as $45 \%$ of the periodic increment.

While under historic climate differences in damaged timber volume between management alternatives were negligible, under climate change scenarios the damages by bark beetles intensified and contrasts between management scenarios increased. Under climate change volume stocks and damages by bark beetle disturbances were positively correlated for three reasons: (1) in a warmer climate more beetles could develop because of faster life cycle completion, (2) higher stocks increased the susceptibility of stands to bark beetle damages (see Schroeder 2001; Stadelmann et al. 2013; Hlásny and Turčáni 2013) and (3) more volume is killed by beetles when stocks are high (e.g. Hanewinkel et al. 2011).

Nevertheless comparing the management scenarios with the lowest (STRIP-HI-P) and highest (NOM) bark beetle damages, only between $39 \%$ (c1) and 34\% (c5) of the expected increase in damages may be prevented by forest management. Under climate change conditions NOM might not be a realistic option any more, due to legal requirements for proactive sanitary cuttings to prevent large-scale bark beetle outbreaks and spillover effects on nearby forests (Kautz et al. 2011b; Brůna et al. 2013). Large-scale implementation of selective sanitary management, as proposed in the SAN scenario, may be very costly and requires specialized personnel and support by remote sensing approaches to identify and locate bark beetle-infested trees (e.g. Stadelmann et al. 2013; Fassnacht et al. 2014).

Disturbances bear the potential to negatively influence provisioning of ecosystem services (Thom and Seidl 2016). Given the dominance of Norway spruce in the study area assessing future ES provisioning without consideration of the bark beetle disturbance regime would therefore provide unreliable results. However, in most of the more recent model-based climate change assessments in Central European spruce forests, bark beetle disturbances were not considered at all (e.g. Hlásny et al. 2014; Schuler et al. 2016; Mina et al. 2015). The PICUS bark beetle submodel used for this study (cf., Seidl et al. 2007a) is based on phenological principles of insect development and a predisposition approach to estimate damage risk. Compared to earlier PICUS stand-level applications (Seidl et al. 2011) the simultaneously simulated forest area was increased to about 20 ha in the current study. This corresponds well to the reported extent of consecutive bark beetle damages, where new infestations occur within distances of $250 \mathrm{~m}$ from previous attacks (Kautz et al. 2011a).

The simulated bark beetle-induced tree mortality was directly related to volume (e.g. Pasztor et al. 2014), which in turn correlates with carbon storage on site. Thus a similar trend over management alternatives and climate scenarios evolved. Compared to the average carbon pool of $201.1 \mathrm{t} \mathrm{ha}^{-1}$ in Austrian forests (Weiss et al. 2000) only the high-intensity management alternatives under strong warming resulted in lower carbon storage in our study catchment. Under strong warming also no-harvest alternatives (NOM and SAN) were barely able to maintain initial carbon pools. Negative effects of climate change on carbon stocks through bark beetle infestations are partly buffered, because increased tree mortality first increased deadwood and subsequently soil carbon pools. Overall these results indicate that in situ mitigation potential of Norway spruce mountain forests under climate change is limited (compare Nabuurs et al. 2013).

In contrast to mean volume and carbon stocks impacts on protection services against gravitational hazards, bird habitat quality and tree diversity are much more depending on how damages (i.e. volume of trees affected per damage event) are distributed over the landscape and subsequently affect stand structure. 
In the applied PICUS modelling environment tree mortality caused by bark beetle infestations and senescence was the main source of stochasticity in model results and thus in indicator uncertainty (see Supplementary Material). Accordingly simulation repetitions were necessary to analyse the variability of results. Under a warmer future climate beetle population build-up was faster and more homogeneous between years, and therefore, the variability of simulated damages was decreasing. This simulated behaviour of disturbance damage is supported by findings in Seidl et al. (2016).

Browsing of tree regeneration by wild ungulates was another disturbance factor in our analysis, and it turned out to be the main reason why tree species diversity was relatively insensitive to management intensity and cutting pattern. That selective browsing of admixed tree species can heavily affect species composition in the long run has been confirmed by many empirical (Klopcic et al. 2009; Schulze et al. 2014; Winter et al. 2015) and modelling studies (Didion et al. 2009; Cailleret et al. 2014). The employed browsing probabilities in all management alternatives were based on local inventory results and reflected current conditions in the study area. Browsing intensity was kept constant throughout the simulations. However, in the long run management changed habitat structure which, at same ungulate density, may change the browsing impact. In particular clear cutting in narrow strips has a high predisposition to game damage (Vospernik and Reimoser 2008). In contrast selective small-scale silvicultural interventions may result in less impact by ungulate game on forest vegetation, though hunting might be more difficult (Reimoser and Gossow 1996). A limitation of the analysis set-up was that browsing by ungulates was not implemented in a full factorial design as were management and climate. Without a dedicated analysis of different browsing intensities one can just speculate about effects of reduced browsing pressure on mid- and long-term forest development and related ES provisioning.

\section{Effects of management on ecosystem service provisioning}

Timber harvests, performed in long return intervals (i.e. low intensity), are the current strategy of BAU management, generating income from timber while maintaining other ES at acceptable levels. However, it is not defined explicitly what those minimum levels are and which ES are prioritized at small scale. Our general findings show that none of the analysed alternatives is best for all ES. Below we discuss how our results could be interpreted in the context of adaptive management, if only one ES is prioritized at local scale while total ES value is accounted for at the regional level.
With high emphasizes on timber production higher management intensity is preferable. Under currently practiced low-intensity management the periodic increment is not fully utilized and timber stocks will increase further. If timber production was the only management goal, STRIP pattern would be the best option.

If carbon storage on site is considered, the NOM scenario obviously would be beneficial; however, less fibre is available to supply bioeconomy, feed the wood products pool and produce green energy (FAO 2016), and the carbon sink in the forest will be saturated once (Nabuurs et al. 2014). Considering carbon storage as a secondary ES to be maximized highly dispersed cutting patterns (SLIT) served best.

Protection efficiency against gravitational hazards benefitted from higher stand density under SAN and NOM, and all low-intensity management scenarios. However, protection against avalanche release, and particularly against rockfall, requires that the structure of the tree population remains balanced and comprises of large living trees but also of sufficient numbers of smaller trees (Dorren et al. 2004; Frehner et al. 2005). NOM and SAN are, relatively seen, the best alternatives for rockfall protection, however, at partly very low performance levels and decreasing resilience in the future. Regarding the cutting pattern in low-intensity management scenarios no significant improvement resulted from highly dispersed SLIT patterns compared to currently used PATCH management.

The ES nature conservation and biodiversity showed diverging results. If bird habitat needs to be provided, closed canopies in dense stands are detrimental. Thus interestingly the NOM alternative did not generate the highest shares of good bird habitat. SAN decreased the pool of large snags and was not beneficial for habitat provisioning either. Therefore, low-intensity management using dispersed cutting patterns (SLIT or PATCH) was the best options for bird habitat provisioning, as they kept the canopy layer open and provided enough large snags and veteran trees. Size diversity of the tree population was clearly positively affected by active management scenarios, where management intensity was much more influential than cutting pattern.

\section{Climate change and interaction effects on ecosystem services}

Direct effects of temperature and precipitation on forest dynamics were clearly less important than effects of management. Indirectly climate change affected forest structures and related ES via the disturbance regime. Under a warmer climate damages from bark beetle disturbances increased substantially and thus provided large amounts of deadwood and canopy gaps. These effects supported bird 
habitat quality in dependence of management. For instance NOM in severe climate change scenarios provided best habitat quality, while under historic climate and mild climate change canopy closure was too high.

Further complex interrelationships among ES indicators do occur. For instance the interrelationship between available deadwood for bird habitat and bark beetle-induced tree mortality. Woodpeckers may play a significant role in regulating bark beetle populations. Especially for three-toed woodpeckers, strong response of bird numbers during a gradation of bark beetle was observed (Yaeger 1955; Pechacek 1994). If woodpeckers aggregate at a disturbance site, they may kill between 45 and $98 \%$ of bark beetles by direct (consumption) or indirect (debarking) effects (Fayt et al. 2005). But research also shows complex interactions between bird population dynamics at landscape scale and local consumer-resource relationships (see Fayt et al. 2005): the predatory impact of woodpeckers will depend mostly on the presence of juvenile woodpeckers across the landscape when beetle larvae reach an adequate size. Important factors are therefore reproductive success of the regional bird population and habitat connectivity. Furthermore under endemic conditions woodpeckers depend on pray other than bark beetle (e.g. longhorn beetle larvae), especially during reproduction season because of higher caloric content (Pechacek and Kristin 2004). As proposed in this study the presence of sufficient large standing deadwood and the presence of veteran trees in general may serve as important food source for woodpecker species during lower beetle population densities. Thus a high bird habitat rating across the landscape is expected to dampen disturbances and result in lower bark beetle-induced tree mortality.

The complexity of functional relationships among ES indicators and how these are affected by management and climate change has been discussed above for bird habitat quality. Several feedback relations exist also for the tree regeneration process. Simulated regeneration progressed slowly under all management alternatives. This is in line with empirical studies in Alpine mountain forests showing that with patch and slit cut approaches successful regeneration may require several decades (Brang 1998; Streit et al. 2009). A warmer climate will generally accelerate regeneration processes and improve the competitiveness of broad-leaved tree species. However, the strong browsing pressure prevented the increase in tree species diversity, regardless of the applied cutting pattern.

\section{Implications for multifunctional adaptive mountain forest management}

The general finding of the presented study was that none of the analysed alternatives is best for all ES and that it requires a more in depth analysis of $\mathrm{ES}$ priorities to establish a long-term strategy for forest management. The dilemma in deciding for a management strategy is in the fact that speeding up the increase in species diversity and the patchiness of forest structure by reducing volume stocks and initiating canopy gaps as an adaptive strategy will, at least temporarily, negatively affect protective services. If spatial disentangling of required services is possible, zoning would be the best solution where in each zone a set of specific ES and priorities would be addressed (Nitschke and Innes 2008; Côté et al. 2010). Management in each zone is then focussed on a subset of predefined ES (Messier et al. 2009), and total ES value can be maximized on the regional level. Socially acceptable prioritization of ES demands is a prerequisite for such zoning approaches.

From our results we conclude that PATCH and SLIT regimes appear as compromise if multifunctionality at small scale is the goal. However, at currently practiced management intensity such management approaches would not be suitable to adapt forest composition and structure to a warming climate. Intensifying disturbances from bark beetles may increase dramatically and impede protective services. Results indicate that increased management intensities at the level of analysed HI variants may moderately reduce bird habitat quality and protective services, but will also reduce forest susceptibility for bark beetle disturbances and has the potential to speed up the increase in admixed species shares, which in turn will positively feedback on susceptibility and foster resilience of forests (e.g. Ammer 1996; Bolte et al. 2009; Didion et al. 2009; Schuler et al. 2016). As a prerequisite for the latter browsing intensity on tree regeneration must be reduced (Winter et al. 2015). In a warmer climate substantial sanitation efforts may be required to control large-scale bark beetle outbreaks (e.g. Triebenbacher 2014) and to keep resulting unstocked areas small. If browsing by ungulates is no longer the main limiting factor, regeneration dynamics are expected to benefit from a warmer climate and longer vegetation periods. In addition artificial regeneration can be used to reduce periods of limited ES provisioning on disturbed areas and to increase the share of admixed tree species in a targeted approach.

Acknowledgements Open access funding provided by University of Natural Resources and Life Sciences Vienna (BOKU). We are grateful to the Stand Montafon Forstfonds for providing internal data and support, with special thanks to Hubert Malin and Bernhard Maier for their interest in scientific research. This study was supported financially by the project ARANGE (Advanced Multifunctional Forest Management in European Mountain Ranges) under the European Union FP7-KBBE funding programme (Grant No. 289437). Two reviewers and Harald Bugmann provided helpful comments on an earlier version of the manuscript. 
Open Access This article is distributed under the terms of the Creative Commons Attribution 4.0 International License (http://crea tivecommons.org/licenses/by/4.0/), which permits unrestricted use, distribution, and reproduction in any medium, provided you give appropriate credit to the original author(s) and the source, provide a link to the Creative Commons license, and indicate if changes were made.

\section{References}

Ammer C (1996) Impact of ungulates on structure and dynamics of natural regeneration of mixed mountain forests in the Bavarian Alps. For Ecol Manag 88:43-53. doi:10.1016/S03781127(96)03808-X

Bentz BJ, Régnière J, Fettig CJ, Hansen EM, Hayes JL, Hicke JA, Kelsey RG, Negrón JF, Seybold SJ (2010) Climate change and bark beetles of the western United States and Canada: direct and indirect effects. Bioscience 60:602-613. doi:10.1525/bio.2010. 60.8 .6

Bitterlich W (1952) Die Winkelzählprobe. Forstwissenschaftliches Cent 71:215-225

Bolte A, Ammer C, Löf M, Madsen P, Nabuurs G-J, Schall P, Spathelf P, Rock J (2009) Adaptive forest management in central Europe: climate change impacts, strategies and integrative concept. Scand J For Res 24:473-482. doi:10.1080/ 02827580903418224

Brang P (1998) Early seedling establishment of Picea abies in small forest gaps in the Swiss Alps. Can J For Res 28:626-639. doi:10. 1139/x98-035

Brang P, Spathelf P, Larsen JB, Bauhus J, Boncina A, Chauvin C, Drossler L, Garcia-Guemes C, Heiri C, Kerr G, Lexer MJ, Mason B, Mohren F, Muhlethaler U, Nocentini S, Svoboda M (2014) Suitability of close-to-nature silviculture for adapting temperate European forests to climate change. Forestry 87:492-503. doi:10.1093/forestry/cpu018

Briner S, Huber R, Bebi P, Elkin C, Schmatz DR, Grêt-Regamey A (2013) Trade-offs between ecosystem services in a mountain region. Ecol Soc 18:35. doi:10.5751/ES-05576-180335

Brůna J, Wild J, Svoboda M, Heurich M, Müllerová J (2013) Impacts and underlying factors of landscape-scale, historical disturbance of mountain forest identified using archival documents. For Ecol Manag 305:294-306. doi:10.1016/j.foreco.2013.06.017

Bugmann H, Cordonnier T, Truhetz H, Lexer MJ (2017) Impacts of business-as-usual management on ecosystem services in European mountain ranges under climate change. Reg Environ Change 17:3-16. doi:10.1007/s10113-016-1074-4

Büntgen U, Frank DC, Schmidhalter M, Neuwirth B, Seifert M, Esper J (2006) Growth/climate response shift in a long subalpine spruce chronology. Trees Struct Funct 20:99-110. doi:10.1007/ s00468-005-0017-3

Burschel P, Huss J (2003) Grundriss des Waldbaus: Ein Leitfaden für Studium und Praxis. Ulmer, Stuttgart

Bußjäger P (2007) zu Luxusbauten wird kein Holz verabfolgt! - Die Geschichte des Forstfonds des Standes Montafon. In: Malin H, Maier B, Dönz-Breuß M (eds) Montafoner Standeswald-Montafoner Schriftenr. 18. Heimatschutzverein Montafon, Schruns, pp 9-24

Buttoud G (2000) Approaches to multifunctionality in mountain forests. In: Price MF, Butt $\mathrm{N}$ (eds) Forests in sustainable mountain development: a state of knowledge report for 2000 . IUFRO Research Series 5. CABI Publishing, Wallingford, pp 187-193

Cailleret M, Heurich M, Bugmann H (2014) Reduction in browsing intensity may not compensate climate change effects on tree species composition in the Bavarian Forest National Park. For Ecol Manag 328:179-192. doi:10.1016/j.foreco.2014.05.030

Carpenter SR, Mooney HA, Agard J, Capistrano D, Defries RS, Díaz S, Dietz T, Duraiappah AK, Oteng-Yeboah A, Pereira HM, Perrings C, Reid WV, Sarukhan J, Scholes RJ, Whyte A (2009) Science for managing ecosystem services: Beyond the Millennium Ecosystem Assessment. Proc Natl Acad Sci USA 106:1305-1312. doi:10.1073/pnas.0808772106

Cordonnier T, Courbaud B, Berger F, Franc A (2008) Permanence of resilience and protection efficiency in mountain Norway spruce forest stands: a simulation study. For Ecol Manag 256:347-354. doi:10.1016/j.foreco.2008.04.028

Cordonnier T, Berger F, Elkin C, Lämas T, Martinez M (2013) Deliverable D2.2. Models and linker functions (indicators) for ecosystem services. ARANGE Project Deliverable. http://www. arange-project.eu/wp-content/uploads/ARANGE-D2.2_Modelsand-linker-functions.pdf

Côté P, Tittler R, Messier C, Kneeshaw DD, Fall A, Fortin MJ (2010) Comparing different forest zoning options for landscape-scale management of the boreal forest: possible benefits of the TRIAD. For Ecol Manag 259:418-427. doi:10.1016/j.foreco. 2009.10.038

Didion M, Kupferschmid AD, Lexer MJ, Rammer W, Seidl R, Bugmann H (2009) Potentials and limitations of using largescale forest inventory data for evaluating forest succession models. Ecol Modell 220:133-147. doi:10.1016/j.ecolmodel. 2008.09.021

Dorren LK, Berger F, Imeson AC, Maier B, Rey F (2004) Integrity, stability and management of protection forests in the European Alps. For Ecol Manag 195:165-176. doi:10.1016/j.foreco.2004. 02.057

Drever MC, Aitken KEH, Norris AR, Martin K (2008) Woodpeckers as reliable indicators of bird richness, forest health and harvest. Biol Conserv 141:624-634. doi:10.1016/j.biocon.2007.12.004

EEA (2010) Europe's ecological backbone: recognising the true value of our mountains. In: Agency EE (ed) EEA Report no. 6

Elkin C, Gutiérrez AG, Leuzinger S, Manusch C, Temperli C, Rasche L, Bugmann H (2013) A $2{ }^{\circ} \mathrm{C}$ warmer world is not safe for ecosystem services in the European Alps. Glob Change Biol 19:1827-1840. doi: $10.1111 / \mathrm{gcb} .12156$

FAO (2016) Forestry for a low-carbon future. FAO Forestry Paper 177. Rome

Faria JC, Jelihovschi E, Allaman I (2016) Conventional Tukey Test. UESC, Ilheus

Fassnacht FE, Latifi H, Ghosh A, Joshi PK, Koch B (2014) Assessing the potential of hyperspectral imagery to map bark beetleinduced tree mortality. Remote Sens Environ 140:533-548. doi:10.1016/j.rse.2013.09.014

Fayt P, Machmer MM, Steeger C (2005) Regulation of spruce bark beetles by woodpeckers-a literature review. For Ecol Manag 206:1-14. doi:10.1016/j.foreco.2004.10.054

Frehner M, Wasser B, Schwitter R (2005) Nachhaltigkeit und Erfolgskontrolle im Schutzwald. Wegleitung für Pflegemassnahmen in Wäldern mit Schutzfunktion. Bundesamt für Umwelt, Wald und Landschaft, Bern

Grabherr G (2000) Biodiversity of mountain forests. In: Price MF, Butt $\mathrm{N}$ (eds) Forests in sustainable mountain development: a state of knowledge report for 2000. Task Force on Forests in Sustainable Mountain Development. CABI, Wallingford, pp 28-51

Grêt-Regamey A, Rabe SE, Crespo R, Lautenbach S, Ryffel A, Schlup B (2014) On the importance of non-linear relationships between landscape patterns and the sustainable provision of ecosystem services. Landsc Ecol 29:201-212. doi:10.1007/s10980-013-9957-y

Griess VC, Acevedo R, Härtl F, Staupendahl K, Knoke T (2012) Does mixing tree species enhance stand resistance against natural 
hazards? A case study for spruce. For Ecol Manag 267:284-296. doi:10.1016/j.foreco.2011.11.035

Hanewinkel M (2011) Multifunktionalität des Waldes. Forum für Wissen, WSL, pp 7-14

Hanewinkel M, Hummel S, Albrecht A (2011) Assessing natural hazards in forestry for risk management: a review. Eur J For Res 130:329-351. doi:10.1007/s10342-010-0392-1

Hartl-Meier C, Dittmar C, Zang C, Rothe A (2014) Mountain forest growth response to climate change in the Northern Limestone Alps. Trees 28:819-829. doi:10.1007/s00468-014-0994-1

Häyhä T, Franzese PP, Paletto A, Fath BD (2015) Assessing, valuing, and mapping ecosystem services in Alpine forests. Ecosyst Serv 14:12-23. doi:10.1016/j.ecoser.2015.03.001

Heinimann HR, Stampfer K, Loschek J, Caminada L (2001) Perspectives on Central European cable yarding systems. In: International Mountain Logging and 11th Pacific Northwest Skyline Symposium, pp 268-279

Helama S, Sutinen R (2016) Inter- and intra-seasonal effects of temperature variation on radial growth of alpine treeline Norway spruce. J Mt Sci 13:1-12. doi:10.1007/s11629-015-3665-9

Hewitt CD, Griggs DJ (2004) Ensembles-based predictions of climate changes and their impacts. In: Eos, p 566

Hlásny T, Turčáni M (2013) Persisting bark beetle outbreak indicates the unsustainability of secondary Norway spruce forests: case study from Central Europe. Ann For Sci 70:481-491. doi:10. 1007/s13595-013-0279-7

Hlásny T, Mátyás C, Seidl R, Kulla L, Merganičová K, Trombik J, Dobor L, Barcza Z, Konôpka B (2014) Climate change increases the drought risk in Central European forests: What are the options for adaptation? For J 60:5-18. doi:10.2478/forj-20140001

Hlásny T, Barka I, Kulla L, Bucha T, Sedmák R, Trombik J (2015) Sustainable forest management in a mountain region in the Central Western Carpathians, northeastern Slovakia: the role of climate change. Reg Environ Change. doi:10.1007/s10113-0150894-y

Hollaus M, Wagner W, Eberhöfer C, Karel W (2006) Accuracy of large-scale canopy heights derived from LiDAR data under operational constraints in a complex alpine environment. ISPRS J Photogramm Remote Sens 60:323-338. doi:10.1016/j.isprsjprs. 2006.05.002

Hollaus M, Wagner W, Maier B, Schadauer K (2007) Airborne laser scanning of forest stem volume in a mountainous environment. Sensors 7:1559-1577. doi:10.3390/s7081559

Höllerl S (2008) Auswirkungen von waldbaulichen Maßnahmen auf die Stabilität (Resistenz und Elastizität) von Fichtenreinbeständen in der Bergmischwaldstufe der Bayerischen Alpen (Diss.). Technischen Universität München

Huber MO, Eastaugh CS, Gschwantner T, Hasenauer H, Kindermann G, Ledermann T, Lexer MJ, Rammer W, Schörghuber S, Sterba $\mathrm{H}$ (2013) Comparing simulations of three conceptually different forest models with National Forest Inventory data. Environ Model Softw 40:88-97. doi:10.1016/j.envsoft.2012.08.003

IPCC (2007) Climate Change 2007: Synthesis Report. Contribution of Working Groups I, II and III to the Fourth Assessment Report of the Intergovernmental Panel on Climate Change [Core Writing Team, Pachauri RK, Reisinger A (eds)]. IPCC. Geneva, Switzerland

Irauschek F, Rammer W, Lexer MJ (2017) Can current management maintain forest landscape multifunctionality in the Eastern Alps in Austria under climate change? Reg Environ Change 17:33-48. doi:10.1007/s10113-015-0908-9

Kautz M, Düll J, Ohser J (2011a) Spatial dependence of random sets and its application to dispersion of bark beetle infestation in a natural forest. Image Anal Stereol 30:123-131. doi:10.5566/ias. v30.p123-131
Kautz M, Dworschak K, Gruppe A, Schopf R (2011b) Quantifying spatio-temporal dispersion of bark beetle infestations in epidemic and non-epidemic conditions. For Ecol Manag 262:598-608. doi:10.1016/j.foreco.2011.04.023

Klopcic M, Jerina K, Boncina A (2009) Long-term changes of structure and tree species composition in Dinaric uneven-aged forests: are red deer an important factor? Eur J For Res 129:277-288. doi:10.1007/s10342-009-0325-z

Kromp-Kolb H, Nakicenovic N, Seidl R et al (2014) Österreichischer Sachstandsberiecht Klimawandel 2014-Synthese. In: Austrian Panel on Climate Change (APCC), Österreichischer Sachstandsbericht Klimawandel 2014. Verlag der Österreichischen Akademie der Wissenschaften, Wien, Österreich, pp 67-131

Landsberg JJ, Waring RH (1997) A generalised model of forest productivity using simplified concepts of radiation-use efficiency, carbon balance and partitioning. For Ecol Manag 95:209-228. doi:10.1016/S0378-1127(97)00026-1

Lexer MJ, Hönninger K (2001) A modified 3D-patch model for spatially explicit simulation of vegetation composition in heterogeneous landscapes. For Ecol Manag 144:43-65. doi:10. 1016/S0378-1127(00)00386-8

Lindner M, Maroschek M, Netherer S, Kremer A, Barbati A, GarciaGonzalo J, Seidl R, Delzon S, Corona P, Kolström M, Lexer MJ, Marchetti M (2010) Climate change impacts, adaptive capacity, and vulnerability of European forest ecosystems. For Ecol Manag 259:698-709. doi:10.1016/j.foreco.2009.09.023

Malek Ž, Boerboom L, Glade T (2015) Future forest cover change scenarios with implications for landslide risk: an example from Buzau Subcarpathians, Romania. Environ Manag 56:1228-1243. doi:10.1007/s00267-015-0577-y

Malin H, Lerch T (2007) Schutzwaldbewirtschaftung im Montafon. In: Malin H, Maier B, Dönz-Breuß M (eds) Montafoner Standeswald - Montafoner Schriftenr. 18. Heimatschutzverein Montafon, Schruns, pp 115-128

Malin H, Maier B (2007) Der Wald - Das grüne Rückgrat des Montafon. In: Malin H, Maier B, Dönz-Breuß M (eds) Montafoner Standeswald - Montafoner Schriftenreihe 18. Heimatschutzverein Montafon, Schruns, pp 91-114

Maroschek M, Rammer W, Lexer MJ (2015) Using a novel assessment framework to evaluate protective functions and timber production in Austrian mountain forests under climate change. Reg Environ Change 15:1543-1555. doi:10.1007/ s10113-014-0691-z

Marzluff JM, Millspaugh JJ, Ceder KR, Oliver CD, Withey J, McCarter JB, Mason CL, Comnick J (2002) Modeling changes in wildlife habitat and timber revenues in response to forest management. For Sci 48:191-202

Messier C, Tittler R, Kneeshaw DD, Gélinas N, Paquette A, Berninger K, Rheault H, Meek P, Beaulieu N (2009) TRIAD zoning in Quebec: experiences and results after 5 years. For Chron 85:885-896. doi:10.5558/tfc85885-6

Mina M, Bugmann H, Klopcic M, Cailleret M (2015) Accurate modeling of harvesting is key for projecting future forest dynamics: a case study in the Slovenian mountains. Reg Environ Change. doi:10.1007/s10113-015-0902-2

Mina M, Bugmann H, Cordonnier T, Irauschek F, Klopcic M, Pardos M, Cailleret M (2017) Future ecosystem services from European mountain forests under climate change. J Appl Ecol 54:389-401. doi: $10.1111 / 1365-2664.12772$

Motta R, Haudemand J-C (2000) Protective forests and silvicultural stability. Mt Res Dev 20:180-187. doi:10.1659/02764741(2000)020[0180:PFASS]2.0.CO;2

Muys B, Hynynen J, Palahi M, Lexer MJ, Fabrika M, Pretzsch H, Gillet F, Briceño E, Nabuurs G-J, Kint V (2011) Simulation tools for decision support to adaptive forest management in Europe. For Syst 3:86. doi:10.5424/fs/201019S-9310 
Nabuurs G-J, Lindner M, Verkerk PJ, Gunia K, Deda P, Michalak R, Grassi G (2013) First signs of carbon sink saturation in European forest biomass. Nat Clim Change 3:792-796. doi:10.1038/ nclimate 1853

Nabuurs G-J, Schelhaas M-J, Hendriks K, Hengeveld G (2014) Can European forests meet the demands of the bio-economy in the future? In: Innes J, Nikolakis W (eds) Forests and globalizations: challenges and opportunities for sustainable development. The Earthscan Forest Library, Routledge, Abingdon, pp 153-165

Nagy L, Grabherr G, Körner C, Thompson D (2003) Alpine biodiversity in space and time: a synthesis. In: Thompson DBA (ed) Alpine biodiversity in Europe. Springer, Berlin

Nepal SK, Chipeniuk R (2005) Mountain tourism: toward a conceptual framework. Tour Geogr 7:313-333. doi:10.1080/ 14616680500164849

Netherer S, Schopf A (2010) Potential effects of climate change on insect herbivores in European forests-General aspects and the pine processionary moth as specific example. For Ecol Manag 259:831-838. doi:10.1016/j.foreco.2009.07.034

Nitschke CR, Innes JL (2008) Integrating climate change into forest management in South-Central British Columbia: an assessment of landscape vulnerability and development of a climate-smart framework. For Ecol Manag 256:313-327. doi:10.1016/j.foreco. 2008.04.026

Nyland RD (1996) Silviculture, concepts and applications. The McGraw-Hill Companies Inc, New York

Ott E, Frehner M, Frey HU, Lüscher PU (1997) Gebirgsnadelwälder. Haupt Verlag, Bern

Pabst RJ, Goslin MN, Garman SL, Spies TA (2008) Calibrating and testing a gap model for simulating forest management in the Oregon Coast Range. For Ecol Manag 256:958-972. doi:10. 1016/j.foreco.2008.05.046

Pasztor F, Matulla C, Rammer W, Lexer MJ (2014) Drivers of the bark beetle disturbance regime in Alpine forests in Austria. For Ecol Manag 318:349-358. doi:10.1016/j.foreco.2014.01.044

Pechacek P (1994) Reaktion des Dreizehenspechts auf eine Borkenkäfergradation. Allg Forst- und Jagdzeitung 12:661

Pechacek P, Kristin A (2004) Comparative diets of adult and young three-toed woodpeckers in a european alpine forest community. J Wildl Manag 68:683-693. doi:10.2193/0022541X(2004)068[0683:CDOAAY]2.0.CO;2

Price M, Kohler T, Wachs T (2000) Mountains of the world: mountain forests and sustainable development. Mountain Agenda, Berne

Raudsepp-Hearne C, Peterson GD (2016) Scale and ecosystem services: how do observation, management, and analysis shift with scale-lessons from Quebec. Ecol Soc 21(3):16. doi:10. 5751/ES-08605-210316

Reimoser F, Gossow H (1996) Impact of ungulates on forest vegetation and its dependence on the silvicultural system. For Ecol Manag 88:107-119. doi:10.1016/S0378-1127(96)03816-9

Rounsevell MDA, Dawson TP, Harrison PA (2010) A conceptual framework to assess the effects of environmental change on ecosystem services. Biodivers Conserv 19:2823-2842. doi:10. 1007/s10531-010-9838-5

Schelhaas M-JM-JM-JJM-J, Nabuurs G-JJG-J, Schuck A (2003) Natural disturbances in the European forests in the 19th and 20th centuries. Glob Change Biol 9:1620-1633. doi:10.1046/j.15298817.2003.00684.x

Schroeder LM (2001) Tree mortality by the bark beetle Ips typographus (L.) in storm-disturbed stands. Integr Pest Manag Rev 6:169-175. doi:10.1023/A:1025771318285

Schuler LJ, Bugmann H, Snell RS (2016) From monocultures to mixed-species forests: is tree diversity key for providing ecosystem services at the landscape scale? Landsc Ecol. doi:10.1007/s10980-016-0422-6
Schulze ED, Bouriaud OB, Wäldchen J, Eisenhauer N, Walentowski H, Seele C, Heinze E, Pruschitzki UP, Dănilă G, Marin G, Hessenmöller D, Bouriaud L, Teodosiu M (2014) Ungulate browsing causes species loss in deciduous forests independent of community dynamics and silvicultural management in Central and Southeastern Europe. Ann For Res 57:1. doi:10.15287/afr.2014.273

Seidl R, Lexer MJ, Jager D, Honninger K (2005) Evaluating the accuracy and generality of a hybrid patch model. Tree Physiol 25:939-951. doi:10.1093/treephys/25.7.939

Seidl R, Baier P, Rammer W, Schopf A, Lexer MJ (2007a) Modelling tree mortality by bark beetle infestation in Norway spruce forests. Ecol Modell 206:383-399. doi:10.1016/j.ecolmodel. 2007.04.002

Seidl R, Rammer W, Jäger D, Currie WS, Lexer MJ (2007b) Assessing trade-offs between carbon sequestration and timber production within a framework of multi-purpose forestry in Austria. For Ecol Manag 248:64-79. doi:10.1016/j.foreco.2007.02.035

Seidl R, Rammer W, Lexer MJ (2009) Estimating soil properties and parameters for forest ecosystem simulation based on large scale forest inventories [Schätzung von Bodenmerkmalen und Modellparametern fur die Waldokosystemsimulation auf Basis einer Großrauminventur]. Allg Forst- und Jagdzeitung 180:35-44

Seidl R, Rammer W, Lexer MJ (2011) Adaptation options to reduce climate change vulnerability of sustainable forest management in the Austrian Alps. Can J For Res 41:694-706. doi:10.1139/x10235

Seidl R, Müller J, Hothorn T, Bässler C, Heurich M, Kautz M (2016) Small beetle, large-scale drivers: how regional and landscape factors affect outbreaks of the European spruce bark beetle. J Appl Ecol 53:530-540. doi:10.1111/1365-2664.12540

Skourtos M, Kontogianni A, Harrison PA (2010) Reviewing the dynamics of economic values and preferences for ecosystem goods and services. Biodivers Conserv 19:2855-2872. doi:10. 1007/s10531-009-9722-3

Stadelmann G, Bugmann H, Meier F, Wermelinger B, Bigler C (2013) Effects of salvage logging and sanitation felling on bark beetle (Ips typographus L.) infestations. For Ecol Manag 305:273-281. doi:10.1016/j.foreco.2013.06.003

Stampfer K (2000) Efficiency of mechanised steep terrain harvesting systems. In: In Proceedings of the 23rd annual meeting of the council on forest engineering and the 81st annual meeting of the Canadian Woodlands Forum, Technologies for New Millennium Forestry. CD ROM. September 11-13, 2000, p 4

Streit K, Wunder J, Brang P (2009) Slit-shaped gaps are a successful silvicultural technique to promote Picea abies regeneration in mountain forests of the Swiss Alps. For Ecol Manag 257:1902-1909. doi:10.1016/j.foreco.2008.12.018

Suda M, Pukall K (2014) Multifunktionale Forstwirtschaft zwischen Inklusion und Extinktion (Essay). Schweizerische Zeitschrift fur Forstwes 165:333-338

R Core Team (2016) R: a language and environment for statistical computing. R Foundation for Statistical Computing, Vienna, Austria. https://www.R-project.org/

Temperli C, Bugmann H, Elkin C (2012) Adaptive management for competing forest goods and services under climate change. Ecol Appl 22:2065-2077. doi:10.1890/12-0210.1

Thom D, Seidl R (2016) Natural disturbance impacts on ecosystem services and biodiversity in temperate and boreal forests. Biol Rev 91:760-781. doi:10.1111/brv.12193

Thornton PE, Hasenauer H, White M (2000) Simultaneous estimation of daily solar radiation and humidity from observed temperature and precipitation: an application over complex terrain in Australia. Agric For Meteorol 104:255-271

Triebenbacher C (2014) Das Borkenkäferjahr 2013 in Bayern: Buchdrucker und Kupferstecher haben die Latenz verlassen, Risiko für 2014 gestiegen. Forstschutz Aktuell 59:23-27 
Uhde B, Andreas Hahn W, Griess VC, Knoke T (2015) Hybrid MCDA methods to integrate multiple ecosystem services in forest management planning: a critical review. Environ Manag. doi:10.1007/s00267-015-0503-3

Villa F, Bagstad KJ, Voigt B, Johnson GW, Portela R, Honzák M, Batker D (2014) A methodology for adaptable and robust ecosystem services assessment. PLoS ONE 9:e91001. doi:10. 1371/journal.pone.0091001

Vospernik S, Reimoser S (2008) Modelling changes in roe deer habitat in response to forest management. For Ecol Manag 255:530-545. doi:10.1016/j.foreco.2007.09.036

Weed AS (2013) Consequences of climate change for biotic disturbances. Ecol Monogr 83:441-470. doi:10.1890/13-0160.1

Weinfurter P (2013) Waldbau in Österreich auf ökologischer Grundlage - Eine Orientierungshilfe für die Praxis, 1st edn. Landwirtschaftskammer Österreich, Wien
Weiss P, Schieler K, Schadauer K, Radunsky K, Englisch M (2000) Die Kohlenstoffbilanz des Österreichischen Waldes und Betrachtungen zum Kyoto-Protokoll. Umweltbundesamt GmbH, Wien

Winter MB, Baier R, Ammer C (2015) Regeneration dynamics and resilience of unmanaged mountain forests in the Northern Limestone Alps following bark beetle-induced spruce dieback. Eur J For Res 134:949-968. doi:10.1007/s10342-015-0901-3

Wolfslehner B, Seidl R (2010) Harnessing ecosystem models and multi-criteria decision analysis for the support of forest management. Environ Manag 46:850-861. doi:10.1007/s00267-0099414-5

Yaeger LE (1955) Two woodpecker populations in relation to environmental change. Condor 57:148-153 